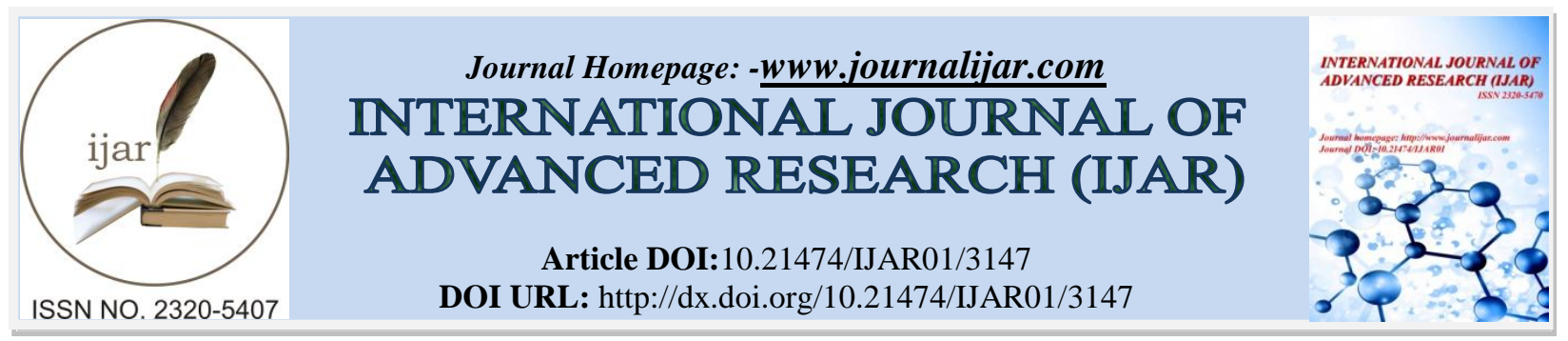

RESEARCH ARTICLE

\title{
PREVALENCE OF MISUSE OF TOPICAL CORTICOSTEROIDS AMONG POPULATIONS IN WESTERN REGION OF SAUDI ARABIA.
}

\section{Dr. Khalid Al Hawsawi, Samaher Alaauldeen, Nouf Albarnawi, Hana Mashrai, Reham Alosaimi, Haneen \\ Alsufyani, Waseem Alhawsawi and Wafaa Abdulkareem Altaezi.}

Consultant Dermatology, King Abdulaziz hospital, Dermatology Department, Makkah, Saudi Arabia.

\section{Manuscript Info}

(..........................

Manuscript History

Received: 01 February 2017

Final Accepted: 20 February 2017

Published: February 2017

Key words:-

Topical corticosteroids (TCS), Misuse,

Non-Prescription Medicines (NPM)

Western Region, Saudi Arabia

\section{Abstract}

This cross - sectional study measured the prevalence of misuse and awareness of Western region populations related to topical corticosteroids (TCS) use and its effects. It also compared the variation of level of awareness and use according to gender, age group and level of education. A sample of 458 participants were selected randomly where a well designed validated self study questionnaire was developed for data collection. Collected data was analyzed using SPSS Ver. 20 where both descriptive and analytical analysis was applied. Main findings included that the problem of TCS and its abuse, misuse, and minimum awareness related to adverse effects to topical drugs have been widespread in Saudi Arabia specially at the Western region of the Kingdom. The study recommended to develop a national policy on Non-Prescription Medicines (NPM) and it should be supported to limit self-medication practice among the Saudi population and to increase their awareness relevant to misuse and adverse side effects of topicalcorticosteroids. Future national studies need to explore the safety and effectiveness of using topicalcorticosteroids.

Copy Right, IJAR, 2017,. All rights reserved.

\section{Introduction:-}

Topical corticosteroids (TCS) are of great value in treating a wide spectrum of dermatological diseases and since the time of its introduction in 1951, a new therapeutic era in dermatology has been emerged (1). The development of super potent corticosteroid in 1974 added more cutaneous diseases to the list of TCS indications. Meanwhile TCS misuse also appeared as a common problem adding a new complication which has been reported by Variety of investigators (2). Chronic misuse of TCS on the face produced a clinical condition which was described by various names, like light sensitive seborrheid, perioral dermatitis (3), rosacea-like dermatitis (4), steroid induced rosacealike dermatitis (4), Steroid Rosacea (5), and steroid dermatitis resembling Rosacea (6).

Topical corticosteroids (TCS) are perhaps the most widely used agents amongst the therapeutic armamentarium and have been rightly acknowledged as a wonder drug in dermatological therapy (7). They provide immediate subjective and objective relief in symptoms in almost all inflammatory dermatoses thus justifying its rampant use. This usefulness of the drug has become a double edged weapon and made alarming proportion of individuals vulnerable to its abuse leading to serious local adverse effects especially on face (8). Vast sections of society have become victims of this magic drug owing to the craze of beautification leading to a virtual epidemic of acneform eruptions,

Corresponding Author:-Dr. Khalid Al Hawsawi.

Address:- Consultant Dermatology, King Abdul-Aziz hospital, Dermatology Department. Makkah. Saudi 
steroid rosacea/steroid dependent facies, telangiectasia, hypertrichosis and premature aged appearance of face. Aim of our study is to make awareness about misuse of TCS.

The adverse effects of TCS tend to occur with prolonged treatment and depend on potency of TS, its vehicle and site of application. The most common include atrophy, striae, rosacea, perioral dermatitis, acne and purpura. Hypertrichosis, pigment alteration, delayed wound healing and exacerbation of skin infections are less frequent (14). Systemic adverse effects from TS have also been described and they are more likely to develop when highly potent TS are used for prolonged periods on thin skin (e.g. face) or on raw/inflamed surfaces $(13,14)$.

\section{Research Objectives:-}

- To measure the Prevalence of misuse of topical corticosteroids among populations in western region of Saudi Arabia.

- To assess the level of awareness of Western region populations related to corticosteroids use and its effects.

- To compare if there any statistical variation between the level of use of corticosteroids and gender.

- To compare if there any statistical variation between the level of use of corticosteroids and age group.

- To compare if there any statistical variation between the level of use of corticosteroids and educational level.

\section{Materials and Methods:-}

Study Design and Sample Size:-

A prospective cross sectional study was conducted in Western Region of Saudi Arabia from October to December 2016. Sample of 458 subjects were selected randomly within the age of 20 up to 65 years old.

\section{Methods and Tools of Data Collection:-}

A validated self-administered pretested questionnaire was devolved and filled by all participants. The questionnaire consisted demographic variables and study variables to achieve study objectives.

Inclusion Criteria:-

- Saudi nationality

- Male and female between (20-65) years old.

- Western region citizens

Data Analysis:-

Collected data was analyzed using SPSS version 20 where descriptive analysis was conducted for basic or demographic data while Chi Square test was applied to calculate correlation between different dependent and independent variables.

\section{Ethical Approval:-}

Approval for research was obtained from Institutional Research Ethics Committee.

\section{Results:-}

\section{Section 1:- Demonstrates Demographic Data}

Table 1:- Shows The Distribution Of Participants According To The Demographic Data

$$
\mathrm{N}=\mathbf{4 5 8}
$$

\begin{tabular}{|l|l|c|c|}
\hline Variable & Category & Fr. & \% \\
\hline \multirow{2}{*}{ Gender } & Male & 137 & 30 \\
\cline { 2 - 4 } & Female & 321 & 70 \\
\hline \multirow{3}{*}{ Age Group in Years } & $<20$ & 50 & 11 \\
\cline { 2 - 4 } & $21-40$ & 302 & 66 \\
\cline { 2 - 4 } & $41-60$ & 101 & 22 \\
\cline { 2 - 4 } & $>61$ & 5 & 1 \\
\hline \multirow{5}{*}{ Educational Level } & Secondary or below & 330 & 72 \\
\cline { 2 - 4 } & Under Graduate & 23 & 5 \\
\cline { 2 - 4 } & Post Graduate & 5 & 22 \\
\hline
\end{tabular}

* Most of participants were female (70\%), within the age group of 21 - 40 years old (66\%) and under graduate students $(72 \%)$. 
Section 2:- Demonstrates Knowledge and practices towards topical corticosteroids

Table and Figure 2 Show The Distribution Of Participants According To The Use of topical corticosteroids $\mathbf{N}=\mathbf{4 5 8}$

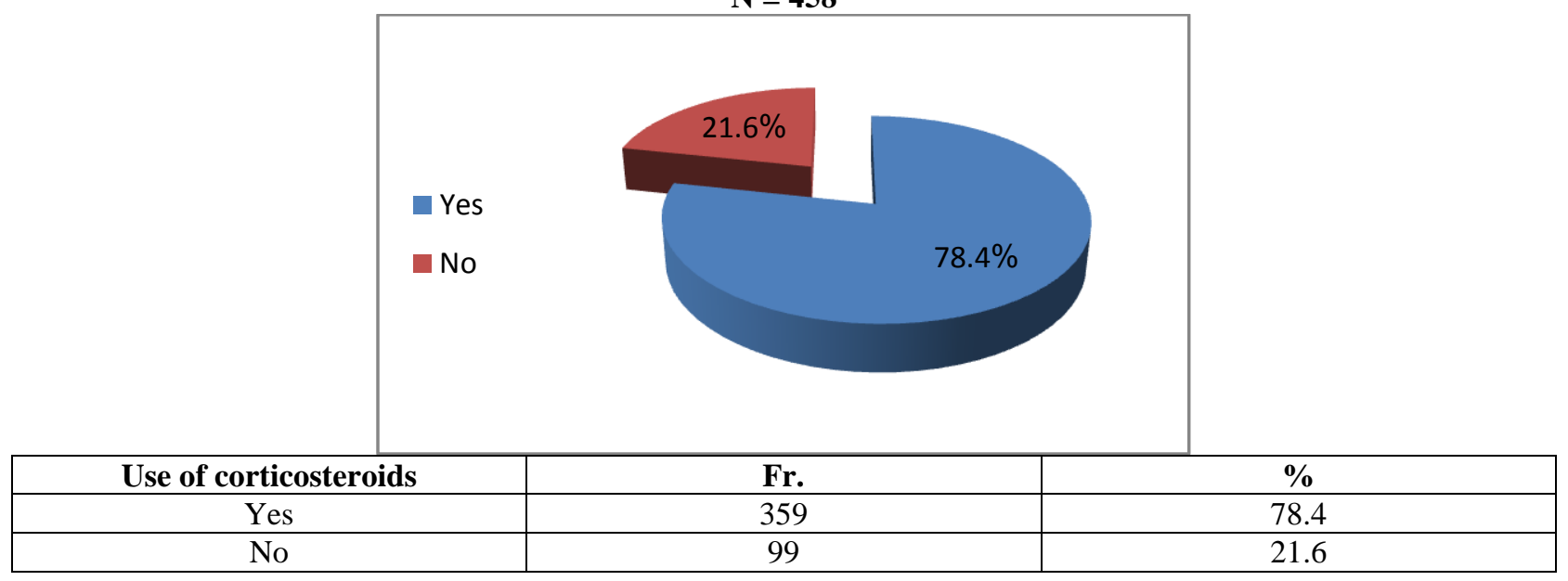

The use of topical corticosteroids among participants was $78 \%$.

Table and Figure 3 Show The Distribution Of Participants According To The Presence Of Prescription for topical corticosteroids

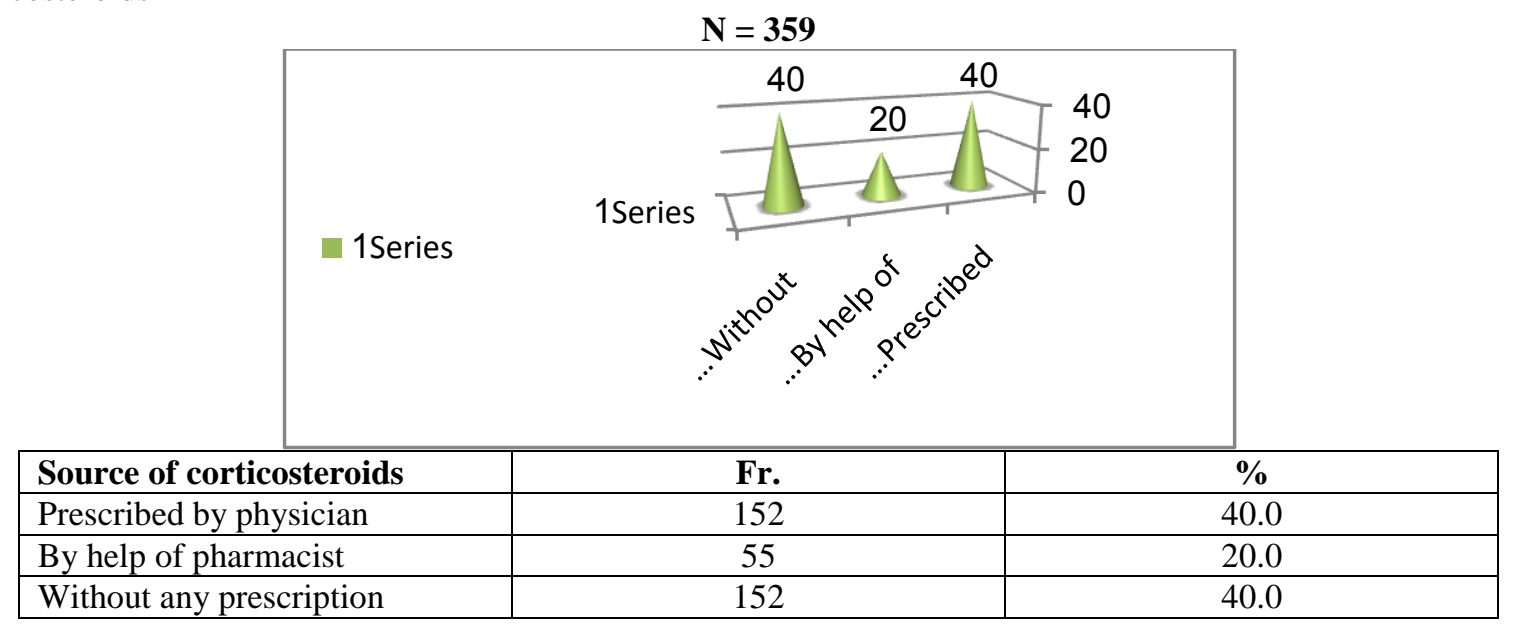

Only $40 \%$ of participants used topical corticosteroids as prescribed by physician who is only authorized person to give different medications

Table and Figure 4 Show The Distribution Of Participants According To The body parts where topical corticosteroids used

\begin{tabular}{|l|l|}
\hline Nace only & N $=359$ \\
$\begin{array}{r}\text { Peripherals \& trunk } \\
\text { only }\end{array}$ \\
$\begin{array}{r}\text { Face ,Peripherals \& } \\
\text { trunk }\end{array}$ \\
genitalia
\end{tabular}




\begin{tabular}{|l|c|c|}
\hline \multirow{2}{*}{ Body part } & \multicolumn{2}{|c|}{ Yes } \\
\cline { 2 - 3 } & Fr. & \% \\
\hline Face only & 91 & 19.9 \\
\hline Peripherals \& trunk only & 119 & 26.0 \\
\hline Face ,Peripherals \& trunk & 51 & 11.1 \\
\hline genitalia & 98 & 21.4 \\
\hline
\end{tabular}

Near to half of participants used topical corticosteroids on face $19.9 \%$

Table and Figure 5 Show The Distribution Of Participants According To The Reasons for use of topical corticosteroids

$$
\mathbf{N}=359
$$

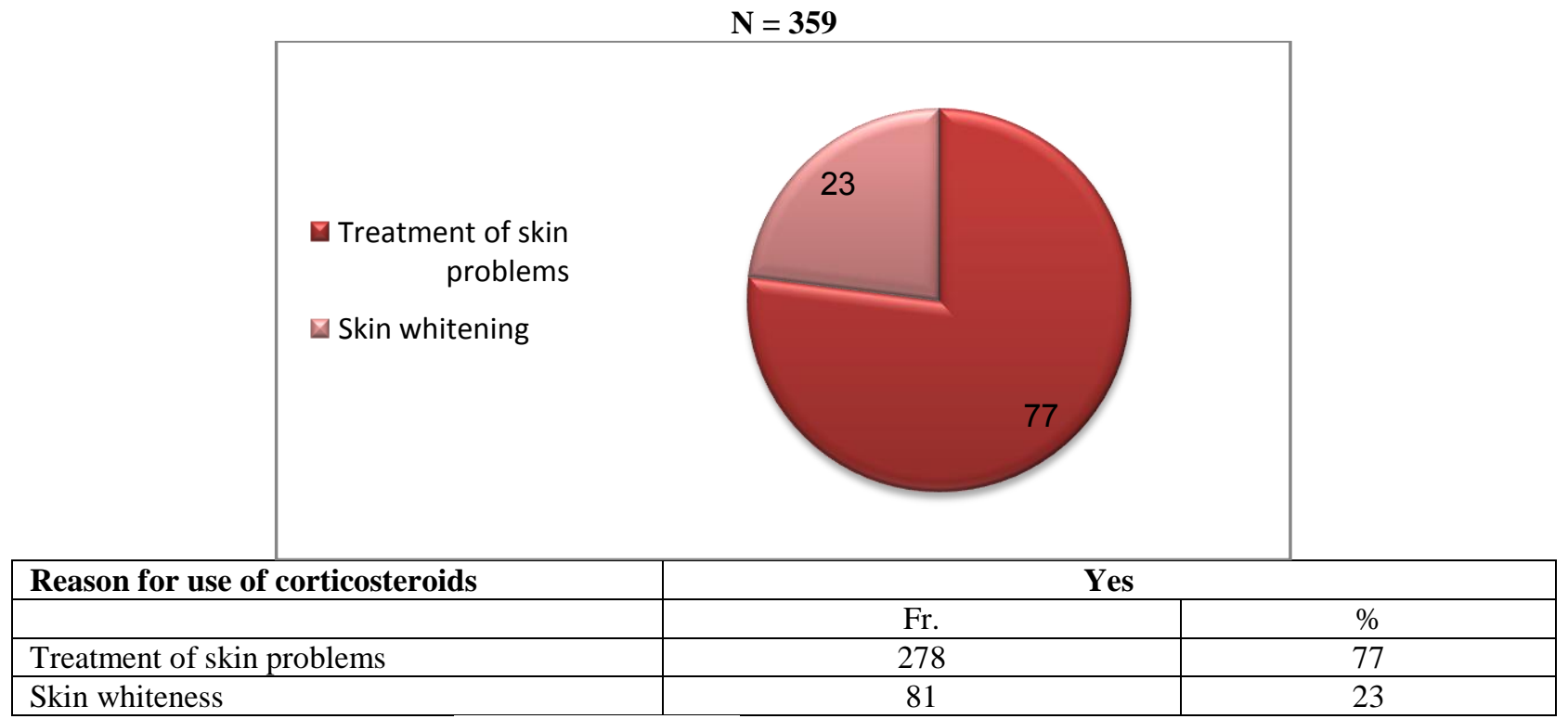

About $23 \%$ of participants used topical corticosteroids for other purposes rather than treatment.

Table and Figure 6 Show The Distribution Of Participants According To The Period of using topical corticosteroids

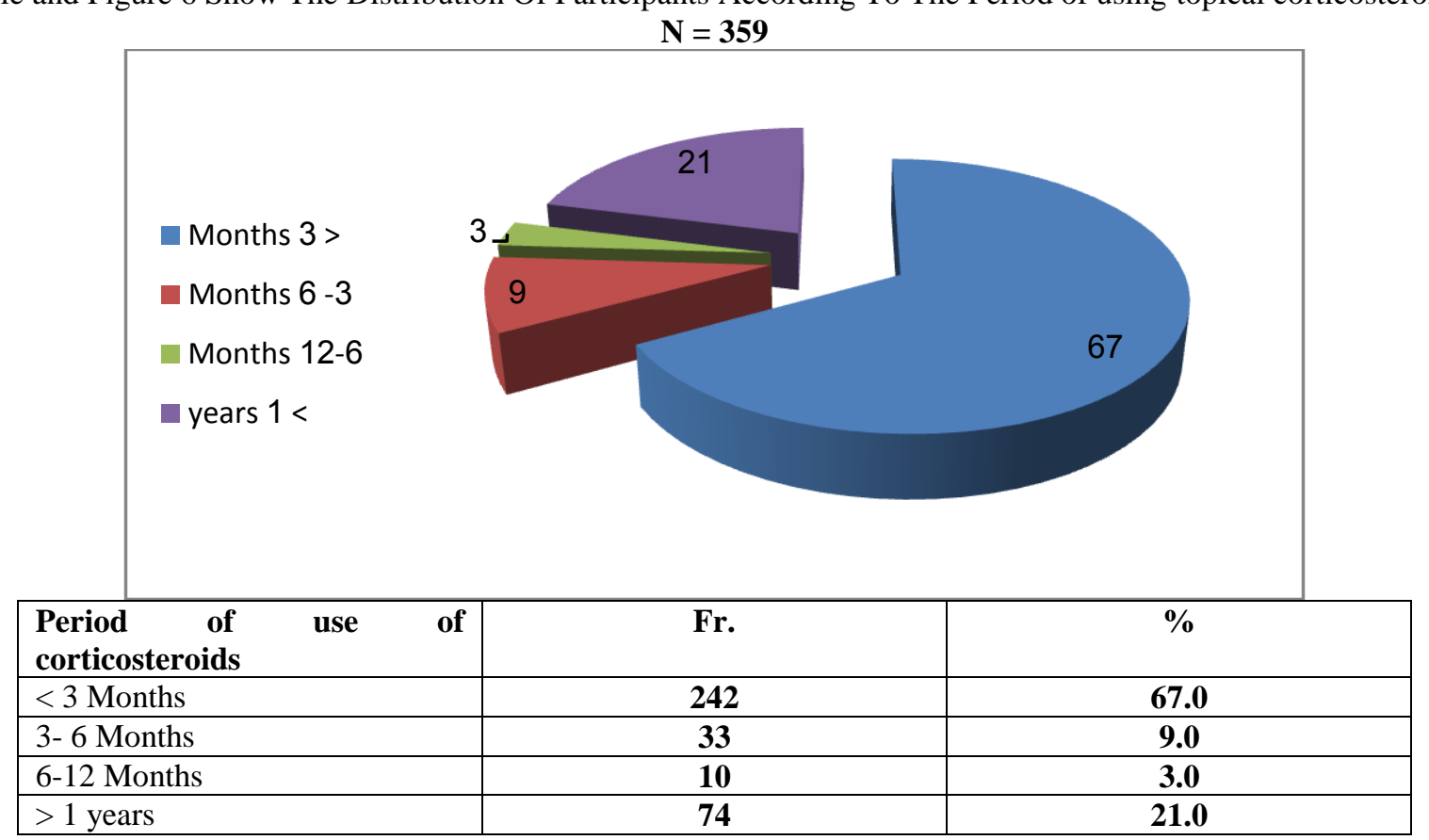


All participants used topical corticosteroids for at least THREE months, while about $21 \%$ used it for one year, Table and Figure 7 Show The Distribution Of Participants According To The way of using topical corticosteroids $\mathbf{N}=359$

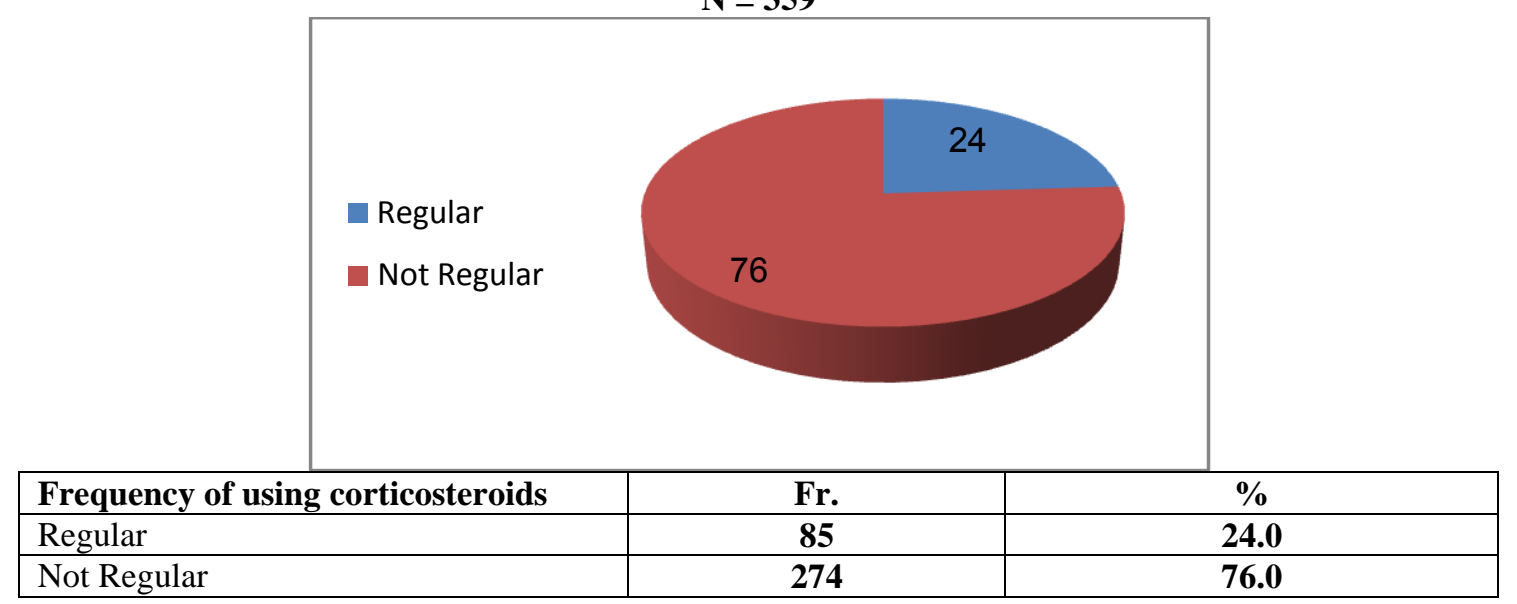

About $24 \%$ of participants used topical corticosteroids on regular basis

Table and Figure 8 Show The Distribution Of Participants According To Their Knowledge about side effects of topical corticosteroids

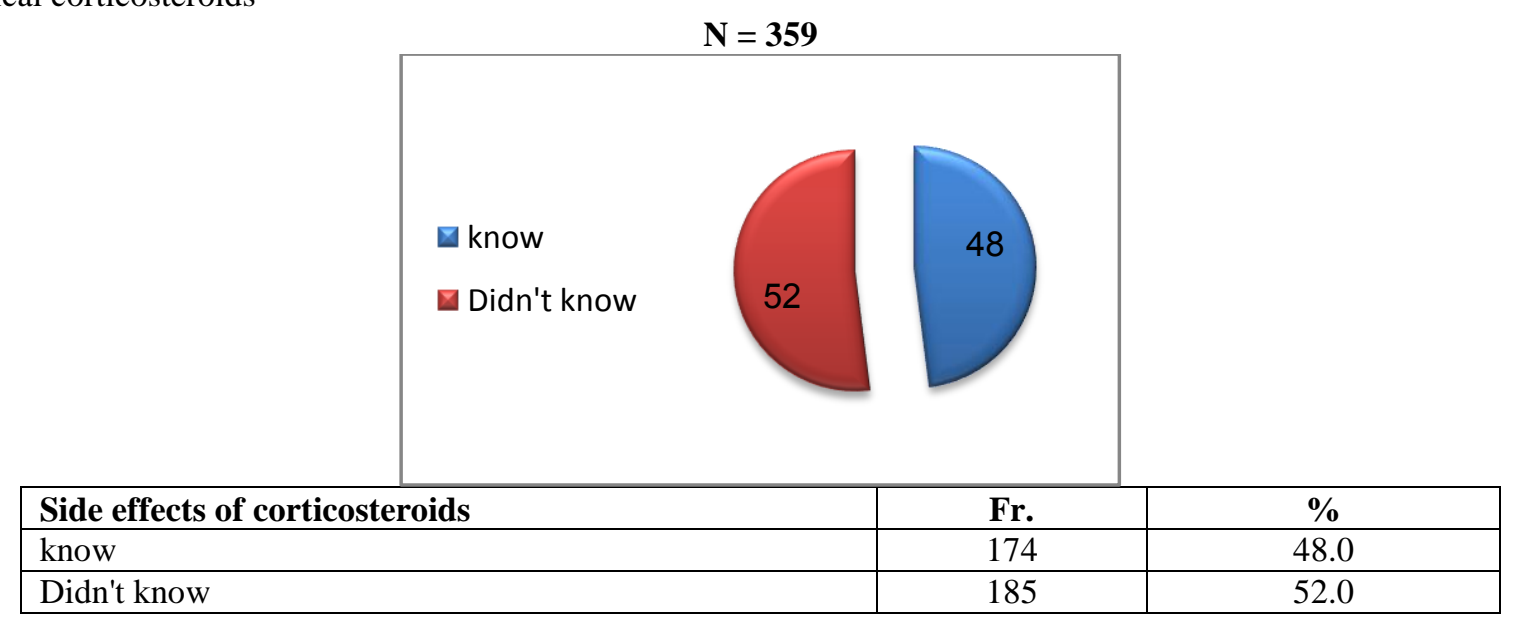

Near to half of participants $(52 \%)$ didn't know the side effects of

Table 9:- Shows The Distribution Of Participants According To Their use of topical corticosteroids and the gender

\begin{tabular}{|c|c|c|c|c|c|c|}
\hline \multirow{2}{*}{\multicolumn{3}{|c|}{ Regular use of topical corticosteroids }} & \multicolumn{2}{|c|}{ gender } & \multirow[t]{2}{*}{ Total } & \multirow[t]{2}{*}{ Sig } \\
\hline & & & male & female & & \\
\hline & \multirow{4}{*}{ yes } & Count & 24 & 55 & 79 & \multirow{12}{*}{0.05} \\
\hline & & $\%$ within regular & $30.4 \%$ & $69.6 \%$ & $100.0 \%$ & \\
\hline & & $\%$ within gender & $23.1 \%$ & $22.5 \%$ & $22.7 \%$ & \\
\hline & & $\%$ of Total & $6.9 \%$ & $15.8 \%$ & $22.7 \%$ & \\
\hline & \multirow{4}{*}{ no } & Count & 80 & 189 & 269 & \\
\hline & & $\%$ within regular & $29.7 \%$ & $70.3 \%$ & $100.0 \%$ & \\
\hline & & $\%$ within gender & $76.9 \%$ & $77.5 \%$ & $77.3 \%$ & \\
\hline & & $\%$ of Total & $23.0 \%$ & $54.3 \%$ & $77.3 \%$ & \\
\hline \multirow{4}{*}{\multicolumn{2}{|c|}{ Total }} & Count & 104 & 244 & 348 & \\
\hline & & $\%$ within regular & $29.9 \%$ & $70.1 \%$ & $100.0 \%$ & \\
\hline & & $\%$ within gender & $100.0 \%$ & $100.0 \%$ & $100.0 \%$ & \\
\hline & & $\%$ of Total & $29.9 \%$ & $70.1 \%$ & $100.0 \%$ & \\
\hline
\end{tabular}


There was statistical relationship between regular use of topical corticosteroids and the gender, female were use more regularly than male, $\mathrm{P}$ Value $<0.05$.

Table 10:- Shows The Distribution Of Participants According To Their knowledge related to side effects of topical corticosteroids and the gender

\begin{tabular}{|c|c|c|c|c|c|c|}
\hline \multicolumn{3}{|c|}{ knowledge related to side effects of topical corticosteroids } & \multicolumn{2}{|c|}{ gender } & \multirow[t]{2}{*}{ Total } & \multirow[t]{2}{*}{ Sig. } \\
\hline & & & \multirow{2}{*}{$\begin{array}{l}\text { male } \\
23\end{array}$} & \multirow{2}{*}{$\begin{array}{r}\text { female } \\
111 \\
\end{array}$} & & \\
\hline & Know & Count & & & 134 & \multirow{12}{*}{0.00} \\
\hline & & $\%$ within side effects & $17.2 \%$ & $82.8 \%$ & $100.0 \%$ & \\
\hline & & $\%$ within gender & $21.5 \%$ & $44.9 \%$ & $37.9 \%$ & \\
\hline & & $\%$ of Total & $6.5 \%$ & $31.4 \%$ & $37.9 \%$ & \\
\hline & Didn't Know & Count & 84 & 136 & 220 & \\
\hline & & $\%$ within side effects & $38.2 \%$ & $61.8 \%$ & $100.0 \%$ & \\
\hline & & $\%$ within gender & $78.5 \%$ & $55.1 \%$ & $62.1 \%$ & \\
\hline & & $\%$ of Total & $23.7 \%$ & $38.4 \%$ & $62.1 \%$ & \\
\hline \multirow{4}{*}{\multicolumn{2}{|c|}{ Total }} & Count & 107 & 247 & 354 & \\
\hline & & $\%$ within side effects & $30.2 \%$ & $69.8 \%$ & $100.0 \%$ & \\
\hline & & $\%$ within gender & $100.0 \%$ & $100.0 \%$ & $100.0 \%$ & \\
\hline & & $\%$ of Total & $30.2 \%$ & $69.8 \%$ & $100.0 \%$ & \\
\hline
\end{tabular}

There was statistical relationship between knowledge related to side effects of topical corticosteroids and the gender, female were more knowledgeable than male, $\mathrm{P}$ Value $<0.05$.

Table 11:- Shows The Distribution Of Participants According To The Source of topical corticosteroids and Gender

\begin{tabular}{|c|c|c|c|c|c|c|}
\hline \multirow{2}{*}{\multicolumn{3}{|c|}{ Source of topical corticosteroids }} & \multicolumn{2}{|c|}{ gender } & \multirow[t]{2}{*}{ Total } & \multirow[t]{2}{*}{ Sig. } \\
\hline & & & \multirow{2}{*}{ male } & \multirow{2}{*}{$\begin{array}{r}\text { female } \\
103\end{array}$} & & \\
\hline & \multirow[t]{4}{*}{ Physician } & Count & & & 147 & \multirow{20}{*}{0.01} \\
\hline & & $\%$ within who prescript & $29.9 \%$ & $70.1 \%$ & $100.0 \%$ & \\
\hline & & $\%$ within gender & $41.1 \%$ & $42.4 \%$ & $42.0 \%$ & \\
\hline & & $\%$ of Total & $12.6 \%$ & $29.4 \%$ & $42.0 \%$ & \\
\hline & \multirow[t]{4}{*}{ Pharmacist } & Count & 25 & 29 & 54 & \\
\hline & & $\%$ within who prescript & $46.3 \%$ & $53.7 \%$ & $100.0 \%$ & \\
\hline & & $\%$ within gender & $23.4 \%$ & $11.9 \%$ & $15.4 \%$ & \\
\hline & & $\%$ of Total & $7.1 \%$ & $8.3 \%$ & $15.4 \%$ & \\
\hline & \multirow{4}{*}{$\begin{array}{l}\text { without any } \\
\text { prescription }\end{array}$} & Count & 19 & 71 & 90 & \\
\hline & & $\%$ within who prescript & $21.1 \%$ & $78.9 \%$ & $100.0 \%$ & \\
\hline & & $\%$ within gender & $17.8 \%$ & $29.2 \%$ & $25.7 \%$ & \\
\hline & & $\%$ of Total & $5.4 \%$ & $20.3 \%$ & $25.7 \%$ & \\
\hline & \multirow{4}{*}{$\begin{array}{l}\text { friends and relatives } \\
\text { or others }\end{array}$} & Count & 19 & 40 & 59 & \\
\hline & & $\%$ within who prescript & $32.2 \%$ & $67.8 \%$ & $100.0 \%$ & \\
\hline & & $\%$ within gender & $17.8 \%$ & $16.5 \%$ & $16.9 \%$ & \\
\hline & & $\%$ of Total & $5.4 \%$ & $11.4 \%$ & $16.9 \%$ & \\
\hline \multirow{4}{*}{\multicolumn{2}{|c|}{ Total }} & Count & 107 & 243 & 350 & \\
\hline & & $\%$ within who prescript & $30.6 \%$ & $69.4 \%$ & $100.0 \%$ & \\
\hline & & $\%$ within gender & $100.0 \%$ & $100.0 \%$ & $100.0 \%$ & \\
\hline & & $\%$ of Total & $30.6 \%$ & $69.4 \%$ & $100.0 \%$ & \\
\hline
\end{tabular}

There was statistical relationship between the source of topical corticosteroids and the gender, females were more use un prescript topical corticosteroids than others, $\mathrm{P}$ Value $<0.05$. 
Table 12:- Shows The Distribution Of Participants According To Their knowledge related to side effects of topical corticosteroids and the level of education

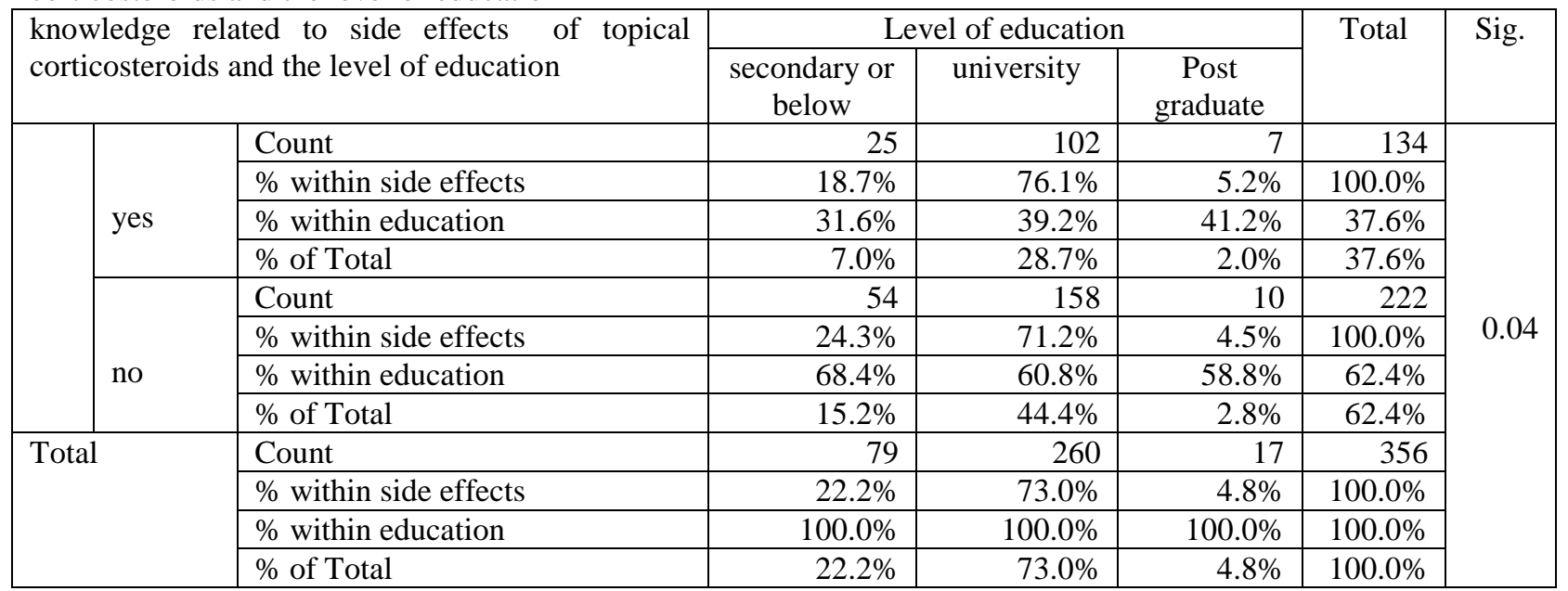

There was statistical relationship between knowledge related to side effects of topical corticosteroids and the level of education, university participants were more knowledgeable than others, $\mathrm{P}$ Value $<0.05$.

Table 13:- Shows The Distribution Of Participants According To Their use of topical corticosteroids and the level of education

\begin{tabular}{|c|c|c|c|c|c|c|c|}
\hline \multirow{2}{*}{\multicolumn{3}{|c|}{ Use of topical corticosteroids }} & \multirow{2}{*}{\multicolumn{3}{|c|}{ Level of education }} & \multirow[t]{2}{*}{ Total } & \multirow[t]{2}{*}{ Sig. } \\
\hline & & & & & & & \\
\hline \multirow[t]{8}{*}{ regular } & \multirow[t]{4}{*}{ yes } & Count & 22 & 57 & 2 & 81 & \multirow{12}{*}{0.029} \\
\hline & & $\%$ within regular & $27.2 \%$ & $70.4 \%$ & $2.5 \%$ & $100.0 \%$ & \\
\hline & & $\%$ within education & $28.2 \%$ & $22.4 \%$ & $11.8 \%$ & $23.1 \%$ & \\
\hline & & $\%$ of Total & $6.3 \%$ & $16.3 \%$ & $.6 \%$ & $23.1 \%$ & \\
\hline & \multirow[t]{4}{*}{ no } & Count & 56 & 198 & 15 & 269 & \\
\hline & & $\%$ within regular & $20.8 \%$ & $73.6 \%$ & $5.6 \%$ & $100.0 \%$ & \\
\hline & & $\%$ within education & $71.8 \%$ & $77.6 \%$ & $88.2 \%$ & $76.9 \%$ & \\
\hline & & $\%$ of Total & $16.0 \%$ & $56.6 \%$ & $4.3 \%$ & $76.9 \%$ & \\
\hline \multirow{4}{*}{\multicolumn{2}{|c|}{ Total }} & Count & 78 & 255 & 17 & 350 & \\
\hline & & $\%$ within regular & $22.3 \%$ & $72.9 \%$ & $4.9 \%$ & $100.0 \%$ & \\
\hline & & $\%$ within education & $100.0 \%$ & $100.0 \%$ & $100.0 \%$ & $100.0 \%$ & \\
\hline & & $\%$ of Total & $22.3 \%$ & $72.9 \%$ & $4.9 \%$ & $100.0 \%$ & \\
\hline
\end{tabular}

There was statistical relationship between regular use of topical corticosteroids and the level of education, university participants were more use than others, $\mathrm{P}$ Value $<0.05$. 
Table 14:- Shows The Distribution Of Participants According To The Source of topical corticosteroids and the level of education

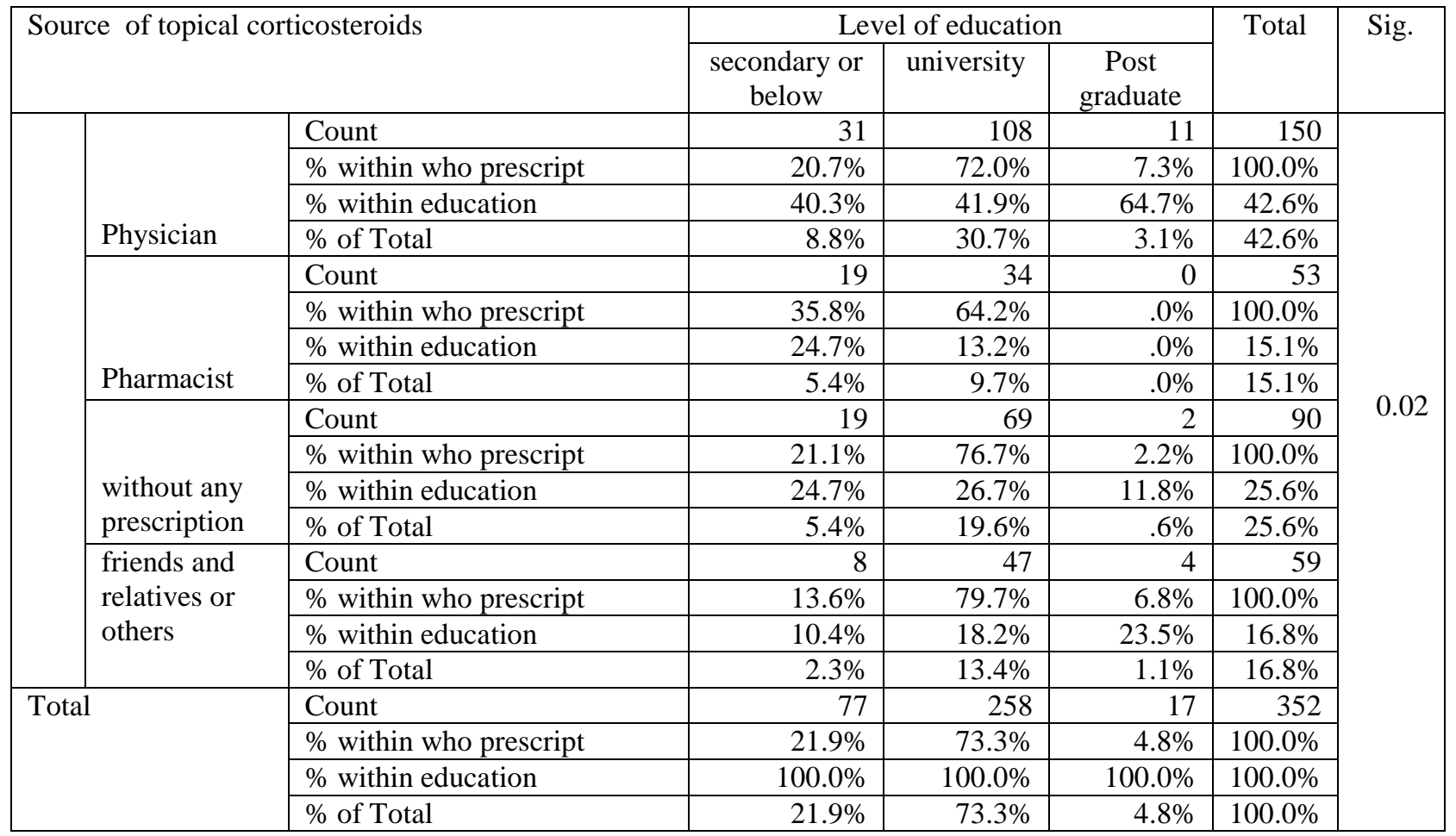

There was statistical relationship between the source of topical corticosteroids and the level of education, university participants were more use un prescript topical corticosteroids than others, $\mathrm{P}$ Value $<0.05$.

Table 15:- Shows The Distribution Of Participants According To The Regular Use of topical corticosteroids and age

\begin{tabular}{|c|c|c|c|c|c|c|c|}
\hline \multirow{2}{*}{\multicolumn{2}{|c|}{$\begin{array}{l}\text { Regular Use of topical } \\
\text { corticosteroids }\end{array}$}} & \multicolumn{4}{|c|}{ Age in Years } & \multirow[t]{2}{*}{ Total } & \multirow[t]{2}{*}{ Sig. } \\
\hline & & $<20$ & $21-40$ & $41-60$ & $>61$ & & \\
\hline \multirow{4}{*}{ yes } & Count & 4 & 51 & 11 & 2 & 68 & \multirow{12}{*}{0.03} \\
\hline & $\%$ within regular & $5.9 \%$ & $75.0 \%$ & $16.2 \%$ & $2.9 \%$ & $100.0 \%$ & \\
\hline & $\%$ within age & $12.5 \%$ & $27.0 \%$ & $16.4 \%$ & $66.7 \%$ & $23.4 \%$ & \\
\hline & $\%$ of Total & $1.4 \%$ & $17.5 \%$ & $3.8 \%$ & $.7 \%$ & $23.4 \%$ & \\
\hline \multirow{4}{*}{ no } & Count & 28 & 138 & 56 & 1 & 223 & \\
\hline & $\%$ within regular & $12.6 \%$ & $61.9 \%$ & $25.1 \%$ & $.4 \%$ & $100.0 \%$ & \\
\hline & $\%$ within age & $87.5 \%$ & $73.0 \%$ & $83.6 \%$ & $33.3 \%$ & $76.6 \%$ & \\
\hline & $\%$ of Total & $9.6 \%$ & $47.4 \%$ & $19.2 \%$ & $.3 \%$ & $76.6 \%$ & \\
\hline \multirow{4}{*}{ Total } & Count & 32 & 189 & 67 & 3 & 291 & \\
\hline & $\%$ within regular & $11.0 \%$ & $64.9 \%$ & $23.0 \%$ & $1.0 \%$ & $100.0 \%$ & \\
\hline & $\%$ within age & $100.0 \%$ & $100.0 \%$ & $100.0 \%$ & $100.0 \%$ & $100.0 \%$ & \\
\hline & $\%$ of Total & $11.0 \%$ & $64.9 \%$ & $23.0 \%$ & $1.0 \%$ & $100.0 \%$ & \\
\hline
\end{tabular}

There was statistical relationship between the source of topical corticosteroids and the age group, age of $21-40$ were more regular of topical corticosteroids than others, $\mathrm{P}$ Value $<0.05$. 
Table 16:- Shows The Distribution Of Participants According To The Source of topical corticosteroids and age

\begin{tabular}{|c|c|c|c|c|c|c|c|c|}
\hline \multirow{2}{*}{\multicolumn{3}{|c|}{ Source of topical corticosteroids }} & \multirow{2}{*}{\multicolumn{4}{|c|}{ age }} & \multirow[t]{3}{*}{ Total } & \multirow[t]{3}{*}{ Sig. } \\
\hline & & & & & & & & \\
\hline \multirow{4}{*}{\multicolumn{2}{|c|}{ Physician }} & Count & $\begin{array}{l}\begin{array}{l}<20 \\
\text { years }\end{array} \\
15\end{array}$ & $\begin{array}{r}21-40 \\
85\end{array}$ & $\begin{array}{r}41-60 \\
27\end{array}$ & $\begin{array}{r}>61 \\
1\end{array}$ & & \\
\hline & & $\%$ within who prescript & $11.7 \%$ & $66.4 \%$ & $21.1 \%$ & $.8 \%$ & $100.0 \%$ & \multirow{19}{*}{0.75} \\
\hline & & $\%$ within age & $45.5 \%$ & $45.7 \%$ & $38.0 \%$ & $33.3 \%$ & $43.7 \%$ & \\
\hline & & $\%$ of Total & $5.1 \%$ & $29.0 \%$ & $9.2 \%$ & $.3 \%$ & $43.7 \%$ & \\
\hline \multirow{4}{*}{\multicolumn{2}{|c|}{ Pharmacist }} & Count & 5 & 25 & 11 & 0 & 41 & \\
\hline & & $\%$ within who prescript & $12.2 \%$ & $61.0 \%$ & $26.8 \%$ & $.0 \%$ & $100.0 \%$ & \\
\hline & & $\%$ within age & $15.2 \%$ & $13.4 \%$ & $15.5 \%$ & $.0 \%$ & $14.0 \%$ & \\
\hline & & $\%$ of Total & $1.7 \%$ & $8.5 \%$ & $3.8 \%$ & $.0 \%$ & $14.0 \%$ & \\
\hline \multirow{4}{*}{\multicolumn{2}{|c|}{$\begin{array}{l}\text { without any } \\
\text { prescription }\end{array}$}} & Count & 6 & 53 & 19 & 1 & 79 & \\
\hline & & $\%$ within who prescript & $7.6 \%$ & $67.1 \%$ & $24.1 \%$ & $1.3 \%$ & $100.0 \%$ & \\
\hline & & $\%$ within age & $18.2 \%$ & $28.5 \%$ & $26.8 \%$ & $33.3 \%$ & $27.0 \%$ & \\
\hline & & $\%$ of Total & $2.0 \%$ & $18.1 \%$ & $6.5 \%$ & $.3 \%$ & $27.0 \%$ & \\
\hline \multirow{4}{*}{\multicolumn{2}{|c|}{$\begin{array}{l}\text { friends and } \\
\text { relatives or } \\
\text { others }\end{array}$}} & Count & 7 & 23 & 14 & 1 & 45 & \\
\hline & & $\%$ within who prescript & $15.6 \%$ & $51.1 \%$ & $31.1 \%$ & $2.2 \%$ & $100.0 \%$ & \\
\hline & & $\%$ within age & $21.2 \%$ & $12.4 \%$ & $19.7 \%$ & $33.3 \%$ & $15.4 \%$ & \\
\hline & & $\%$ of Total & $2.4 \%$ & $7.8 \%$ & $4.8 \%$ & $.3 \%$ & $15.4 \%$ & \\
\hline \multirow{4}{*}{\multicolumn{2}{|c|}{ Total }} & Count & 33 & 186 & 71 & 3 & 293 & \\
\hline & & $\%$ within who prescript & $11.3 \%$ & $63.5 \%$ & $24.2 \%$ & $1.0 \%$ & $100.0 \%$ & \\
\hline & & $\%$ within age & $100.0 \%$ & $100.0 \%$ & $100.0 \%$ & $100.0 \%$ & $100.0 \%$ & \\
\hline & & $\%$ of Total & $11.3 \%$ & $63.5 \%$ & $24.2 \%$ & $1.0 \%$ & $100.0 \%$ & \\
\hline
\end{tabular}

There was no statistical relationship between the source of topical corticosteroids and the age, $\mathrm{P}$ Value $>0.05$.

Table 17:- Shows The Distribution Of Participants According To Their knowledge to the side effects of topical corticosteroids and age

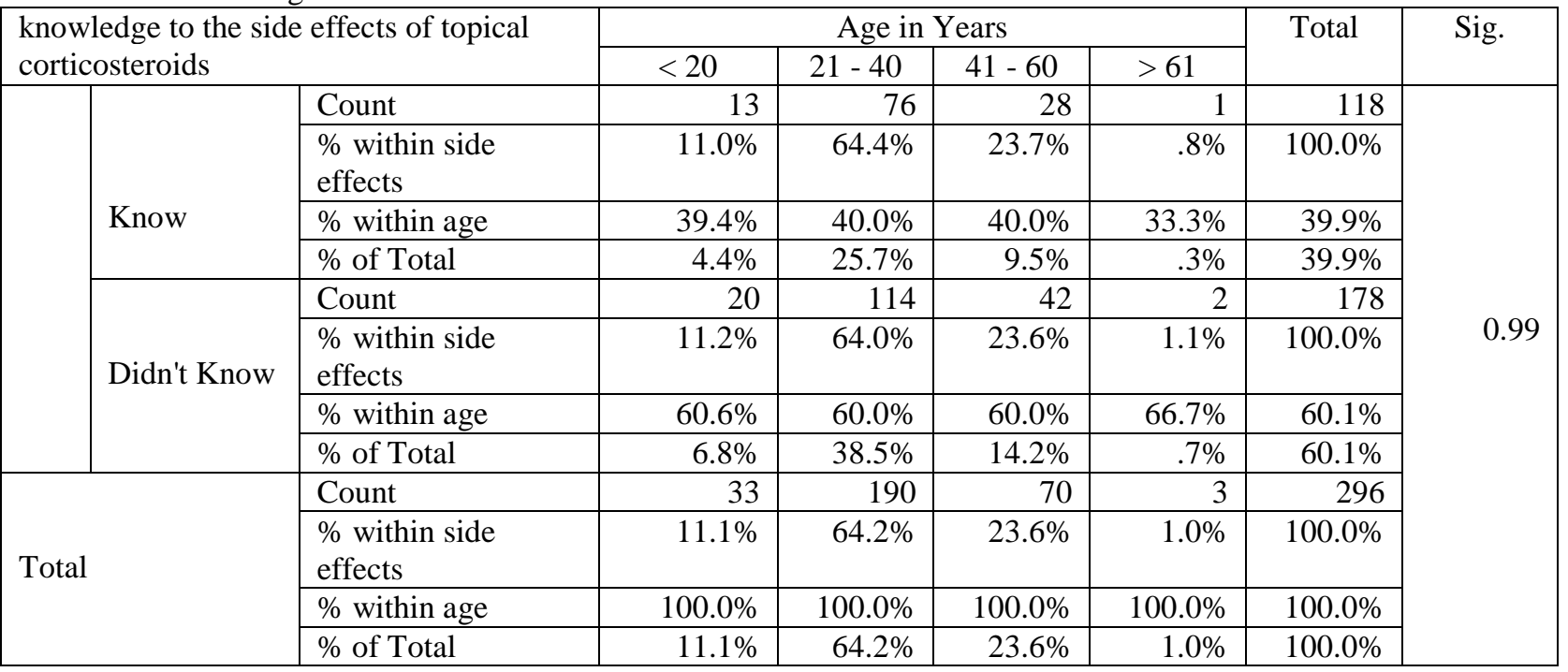

There was no statistical relationship between the participants knowledge towards side effects and the age group, $\mathrm{P}$ Value $<0.05$

\section{Discussion:-}

This study measured the prevalence of misuse and awareness of Western region populations related to corticosteroids use and its effects. It also compared the variation of level of awareness and use according to gender, age group and level of education. 
Misuse of topical corticosteroids appears to be a common problem worldwide, as stated by study, the prevalence of topical corticosteroids misuse was $60 \%$ ( By help of pharmacist or Without any prescription). The use of TCS for kin lightening was statistically significant (23\%). This may also explain the female predominance in this study.

As mentioned in the table (1) 458 individuals were participated in this study where most of them were female ( $70 \%$ ), within age group of 21 - 40 years old (66\%) and under graduate (72\%). The showed that use of topical corticosteroids among participants was $78 \%$. Only $33 \%$ of participants used topical corticosteroids as prescribed by physician who is only authorized person to give different medications while the rest of participants used topical corticosteroids without any prescription or through the advice of pharmacist who is not authorized to give medication. Near to half of participants used topical corticosteroids on face and peripheral, 20\% and $25 \%$. About 39 $\%$ of participants used topical corticosteroids for other purposes rather than treatment. All participants used topical corticosteroids for at least THREE months. Majority of participants (62\%) didn't know the side effects of corticosteroids.

In recent years, there has been an increasing trend for self-medication with non-prescription medicines (NPM). In parallel, more products have been deregulated for purchase without a prescription (11). Population-based survey in developed countries such as Australia, Scotland, United Kingdom and other Asian countries like Taiwan and Singapore found that between a half and two-thirds of the population used NPM, including complementary and over-the-counter medicines (OTC) (12).

Misuse of topical corticosteroids is very common in patients with facial dermatoses. Many patients prefer to use topical steroids as a fairness cream (9). To minimize adverse cutaneous and systemic reactions, especially with prolonged use, the rational use of topical steroids should include careful consideration of the patient's age, total area of application, quantity to be applied, efficacy of the selected corticosteroid, and frequency of application (10). Hence, one step to achieve rational prescribing is periodic auditing of prescriptions.

As shown in tables 8,9 and 10 there was statistical relationship between regular use of topical corticosteroids, side effects, its source and the gender, female were use more regularly, more knowledgeable and more use un prescript topical corticosteroids than others, $\mathrm{P}$ Value $<0.05$.

As shown in tables 11,12 and 13 there was statistical relationship between regular use of topical corticosteroids, side effects, its source and the educational level, under graduate participants were use more regularly, more knowledgeable and more use un prescript topical corticosteroids than others, $\mathrm{P}$ Value $<0.05$.

As shown in tables 14 there was statistical relationship between regular use of topical corticosteroids, and the educational level, age group of 21- 40 years old were use more regularly than others, $\mathrm{P}$ Value $<0.05$ while as shown in table 15 and 16 there was no statistical relationship between the source of topical corticosteroids and knowledge of side effects and the age group, $\mathrm{P}$ Value $>0.05$.

\section{Conclusion:-}

Thus as indicated by data in our study, the problem of TCS and its abuse, misuse, and minimum awareness related to adverse effects to topical drugs have been widespread in Saudi Arabia and specially at the Western region of the Kingdom.

Western region consumers mainly purchased Non Prescript Medications NPM to treat problems of skin, skin lightening and other purposes. The choice of NPM was associated with socio-demographic profile such as gender, age and educational level.

The development of a national policy on NPM should be supported to limit self-medication practice among the Saudi population and to increase their awareness relevant to misuse and adverse side effects of topical corticosteroids. Future national studies need to explore the safety and effectiveness of using topical corticosteroids. 


\section{Reference:-}

1. World Health Organization. Estimated incidence, mortality and 5-year prevalence: both sexes. 2015.

2. Haggar, F. A., \&Boushey, R. P. (2009). Colorectal cancer epidemiology: incidence, mortality, survival, and risk factors. Clinics in colon and rectal surgery, 22(04), 191-197.

3. Macrae, F. (2016). Colorectal cancer: epidemiology, risk factors, and protective factors: Wolters Kluwer, UpToDate. http:// www. uptodate. com/ contents/ colorectal-cancer-epidemiology-risk-factors-and-protectivefactors. Accessed.

4. Alsanea, N., Abduljabbar, A. S., Alhomoud, S., Ashari, L. H., Hibbert, D., \&Bazarbashic, S. (2015). Colorectal cancer in Saudi Arabia: incidence, survival, demographics and implications for national policies. Annals of Saudi medicine, 35(3), 196.

5. Binefa, G., Rodríguez-Moranta, F., Teule, À., \& Medina-Hayas, M. (2014). Colorectal cancer: from prevention to personalized medicine. World J Gastroenterol, 20(22), 6786-6808.

6. Davis, D. M., Marcet, J. E., Frattini, J. C., Prather, A. D., Mateka, J. J., \&Nfonsam, V. N. (2011). Is it time to lower the recommended screening age for colorectal cancer? Journal of the American College of Surgeons, 213(3), 352-361.

7. Nfonsam, V. N., Pandit, V., DiGiovanni, R. M., Ohlson, E., Aziz, H., Jandova, J., \&Gruessner, A. C. (2015). Increased incidence of early onset colorectal cancer in Arizona: a comprehensive 15-year analysis of the Arizona Cancer Registry. Journal of Gastrointestinal \& Digestive System, 2015.

8. Haggstrom, D., \& Cheung, W. Approach to the long-term survivor of colorectal cancer. Nekhlyudov, L., Ed.

9. Saraswat A, Lahiri K, Chatterjee M, Barua S, Coondoo A, Mittal A, et al. Topical corticosteroid abuse on the face: A prospective, multicenter study of dermatology outpatients. Indian J Dermatol Venereol Leprol. 2011;77:160-6. [PubMed].

10. Sweileh WM. Audit of prescribing practices of topical corticosteroids in outpatient dermatology clinics in north Palestine. East Mediterr Health J. 2006;12:161-9. [PubMed].

11. Bond C (2001) POM to P-implications for practice pharmacists. Prim Care Pharm 2: 5-7

12. News (1997) Americans at risk from self-medication, survey reveals. Am J Health Syst Pharm 54: 26642666 [PubMed].

13. Berth-Jones J. Topical therapy. In: Burns T, Breathnach S, Cox N, Griffiths C, editors. Rooks Textbook of Dermatology. 8th ed. 73. Vol. 1. UK: Blackwell Science Ltd; 2010. pp. 1-73.

14. Srinivas CR, Lakshmi C. Principles of topical therapy in dermatology. In: Valia RG, Valia AR, editors. IADVL Textbook of Dermatology. 3rd ed. Vol. 2. Mumbai, India: Bhalani Publishing House; 2008. pp. 1591-618. 